\title{
KEARIFAN EKOLOGI DALAM TRADISI BUBUR SURO DI RANCAKALONG KABUPATEN SUMEDANG
}

\section{ECOLOGICAL WISDOM INBUBUR SURO TRADITION IN RANCAKALONG, SUMEDANG REGENCY}

\author{
Nunung Julaeha ${ }^{1}$, Didin Saripudin ${ }^{2}$, Nana Supriatna ${ }^{3}$, Leli Yulifar ${ }^{4}$ \\ SMA Negeri 1 Sumedang \\ Jl. Prabu Geusan Ulun No. 36, Sumedang \\ Pendidikan Sejarah SPS UPI ${ }^{2,3,4}$ \\ J1. Dr. Setiabudi No. 229 \\ E-mail: nunungjulay.nj@gmail.com ${ }^{1}$, didinsaripudinupi@yahoo.com ${ }^{2}$, nanasup@yahoo.com ${ }^{3}$, \\ leli_yulifar@upi.edu ${ }^{4}$
}

Naskah Diterima: 11 Juni 2019 Naskah Direvisi: 15 September $2019 \quad$ Naskah Disetujui : 28 September 2019

DOI: 10.30959/patanjala.v11i3.538

\begin{abstract}
Abstrak
Tradisi Bubur Suro di Rancakalong Kabupaten Sumedang merupakan kearifan lokal sebagai wujud syukur masyarakat kepada Sang Pencipta serta memiliki fungsi dalam menjaga dan memelihara kesinambungan alam (suistainability). Penelitian yang dilakukan bertujuan untuk mengidentifikasi nilai-nilai kearifan ekologi yang terdapat dalam tradisi Bubur Suro. Masalah penelitian dirumuskan dalam dua pertanyaan penelitian yaitu: (1) Bagaimanakah proses pelaksanaan tradisi Bubur Suro? (2) Nilai-nilai kearifan ekologi apa yang terdapat dalam tradisi Bubur Suro? Metode penelitian adalah deskriftif kualitatif dengan model etnografi. Hasil yang diperoleh menunjukkan terdapat nilai-nilai kearifan lokal dalam tradisi Bubur Suro yang berhubungan dengan upaya masyarakat dalam menjaga kesinambungan hubungan antara manusia dengan manusia, manusia dengan alam, serta manusia dengan sang pencipta. Upaya menjaga kesinambungan alam tampak dalam memelihara keanekaragaman hayati (sarebu rupa), kesinambungan (babasan sarereaeun), hidup hemat dan sederhana (konsep patih goah), hidup tertib dan teratur (tataliparanti, dawegan dipares), gotong-royong serta simbol kersa nyai sebagai bentuk perlindungan terhadap tanaman lokal.
\end{abstract}

Kata kunci: kearifan lokal, kearifan ekologi, tradisi Bubur Suro.

\begin{abstract}
The Bubur Suro tradition in Rancakalong Sumedang is one of the local wisdoms which has a function as an expression of the gratitude of the people to the Creator for mantaining the suistainabality of the cosmos. This research's aims is to identify the values of ecological wisdom contained in Bubur Suro tradition. The problem is formulated into two research questions, namely: (1) How is the Bubur Suro tradition being perfomed? (2) What ecological wisdom values are found in it? The method used is descriptive qualitative method with ethnografic model. The results show that there are local wisdom values in the Bubur Suro tradition which was related to humans efforts to maintain the sustainability of harmonious relationship among fellow human beings, nature, and the Creator. Efforts to preserve the sustainability of nature are evident in maintaining biodiversity (sarebu form), sustainability (babasan sarereaeun), frugal and simple living (patih goah), well-ordered living (tataliparanti, dawegan dipares), mutual cooperation and the symbol of kersa nyai as a form of protection of local plants.
\end{abstract}

Keywords: local wisdom, ecological wisdom, Bubur Suro tradition. 


\section{A. PENDAHULUAN}

Indonesia merupakan negara yang memiliki beragam kebudayaan serta kearifan lokal. Berbagai jenis kebudayaan dan kearifan lokal bisa didapatkan dari berbagai suku bangsa di seluruh Indonesia yang jumlahnya sekitar 500 (Sedyawati, 2014: 7). Nana Supriatna (2016: 3) menggambarkan kekayaan Indonesia yang beragam itu dalam konsep diversitas hayati yang tidak hanya menggambarkan kemajemukan manusia (terutama etnisitas, ras dan kebudayaannya) melainkan juga keanekaragaman mahluk hidup lainnya (flora dan fauna) sebagai sebuah sistem yang saling membutuhkan satu sama lainnya. Sementara Setiyadi (2012: 75) menyatakan bahwa kearifan lokal merupakan adat dan kebiasaan yang telah mentradisi. Kebiasaan tersebut dilakukan oleh sekelompok masyarakat secara turun temurun yang hingga saat ini masih dipertahankan keberadaannya oleh masyarakat hukum adat tertentu di daerah tertentu

Pemerintah Indonesia telah mengatur tentang kearifan lokal dalam UU No.32 tahun 2009 tentang Perlindungan dan Pengelolaan Lingkungan Hidup. Dalam undang-undang tersebut dijelaskan bahwa kearifan lokal adalah nilai-nilai luhur yang berlaku dalam tata kehidupan masyarakat antara lain melindungi dan mengelola lingkungan hidup secara lestari.

Kearifan lokal merupakan hasil kebudayaan manusia, yang menurut Sibarani (2012: 176) memiliki fungsi sebagai pembentukan kepribadian dan karakter yang baik, sebagai penanda identitas atau jati diri sebuah komunitas, sebagai elemen perekat kohesi sosial, sebagai cara pandang (worldview) sebuah komunitas, dan sebagai dasar berinteraksi anggota komunitas. Kearifan lokal terus dipelihara dan dilaksanakan oleh kelompok masyarakatnya melalui penguatan yang terus menerus karena masyarakat merasakan manfaat dan fungsi dari tradisi tersebut. Nilai-nilai kearifan lokal tersebut melekat kuat dalam masyarakat dan teruji sepanjang hidup masyarakat itu sendiri. Kearifan lokal adalah milik kelompok masyarakat tertentu sebagai identitasnya yang bersumber dari nilai budayanya untuk bertindak dan bersikap terhadap lingkungan alam dan lingkungan sosialnya. Identitas yang bersumber dari nilai budaya dalam kelompok masyarakat diharapkan akan mampu meneguhkan identitas sebagai bangsa Indonesia agar mampu menangkal arus deras globalisasi.

Kearifan lokal sebagai hasil kebudayaan manusia bisa dibedakan dalam bentuk hasil budaya yang tampak dan tidak tampak. Identitas atau jati diri sebenarnya sesuatu yang tidak nampak (intangible) yang hanya ada dalam pikiran. Adapun benda-benda nampak (tanggible) hanyalah sarana bagaimana yang tak nampak itu menjadi nampak melalui struktur benda dan tingkah lakunya (Sumardjo, 2011: 16). Pendapat lain menjelaskan bahwa salah satu wujud budaya bukan benda itu adalah tradisi lisan atau folklore, yang terbagi menjadi folklore lisan, folklore sebagian lisan dan folklore bukan lisan (Dananjaja, 1984: 21).

Tradisi lisan menurut Mulyana (2009) berasal dari generasi sebelum generasi sekarang, paling sedikit satu generasi sebelumnya. Berbeda halnya dengan sejarah lisan (oral history), disusun bukan dari generasi sebelumnya tapi disusun oleh generasi sezaman. Asal tradisi lisan dari generasi sebelumnya memiliki fungsi pewarisan, sedangkan di dalam sejarah lisan tidak ada upaya untuk pewarisan. Lebih jauh Mulyana (2009) menjelaskan pesan-pesan yang berupa pernyataan lisan yang diucapkan berasal dari generasi sebelumnya. Kisah yang disampaikan berupa kejadian-kejadian di sekitar kelompok baik sebagai kisah perorangan maupun kelompok seperti cerita kepahlawanan yang mengagumkan bagi kelompok pemiliknya biasanya berpusat pada tokoh tertentu seperti tokoh pemimpin masyarakat.

Adapun menurut Keraf (2010: 369), kearifan lokal mencakup semua bentuk 
pengetahuan, keyakinan, pemahaman, wawasan, serta adat kebiasaan atau etika yang menuntun perilaku manusia dalam kehidupannya di dalam komunitas ekologis. Jadi kearifan lokal ini bukan hanya menyangkut pengetahuan dan pemahaman masyarakat adat tentang manusia dan bagaimana relasi yang baik di antara manusia, melainkan juga menyangkut pengetahuan, pemahaman dan adat kebiasaan tentang manusia, alam dan bagaimana relasi di antara semua penghuni komunitas ekologis ini harus dibangun. Sementara itu, Nasiwan dan Cholisin (2012: 159) berpendapat bahwa kearifan lokal terdiri dari kebijaksanaan atau nilainilai luhur yang terkandung dalam kekayaan-kekayaan budaya lokal seperti tradisi, petatah-petitih dan semboyan hidup.

Berbagai tradisi dan sistem kepercayaan akan tetap bertahan selama kelompok masyarakatnya memiliki fungsi meskipun oleh kelompok di luar masyarakat itu dianggap tidak berfungsi. Fungsi budaya sering dianalogkan sebagai organisme. Dasar fungsional menurut Kaplan dan Manners (2012: 78) sebagaimana ia mengutip Malinowski, adalah asumsi baik yang terbuka maupun tersurat bahwa semua sistem budaya memiliki syarat-syarat fungsional tertentu untuk memungkinkan eksistensinya, yang semuanya harus dipenuhi agar sistem itu bisa bertahan. Dengan lain perkataan, kita harus mengetahui bagaimana kaitan antara institusi-institusi atau struktur-struktur suatu masyarakat sehingga membentuk suatu sistem yang bulat. Kaplan dan Manners (2012) memandang bahwa budaya sebagai sehimpun ciri yang berdiri sendiri, khas dan tanpa kaitan, yang muncul disana-sini karena kebetulan historis.

Bentuk-bentuk kearifan lokal yang bermacam-macam mengakibatkan fungsi kearifan lokal menjadi bermacam-macam pula. Fungsi tersebut antara lain adalah: 1) konservasi dan pelestarian sumber daya alam, 2) mengembangkan sumber daya manusia, 3) pengembangan kebudayaan dan ilmu pengetahuan, dan 4) petuah, kepercayaan, sastra, dan pantangan (Unayah dan Sabarisman, 2012). Sedangkan bentuk kearifan lokal yang masih hidup dalam masyarakat terdiri dari pengetahuan lokal, nilai lokal, ketrampilan lokal, sumber daya lokal serta solidaritas kelompok lokal.

Dari berbagai suku bangsa yang tersebar di seluruh Indonesia salah satu di antaranya adalah etnis Sunda. Etnis Sunda merupakan salah satu etnis yang berada di wilayah administratif Jawa Barat yang biasa disebut tatar Sunda atau Pasundan. Masyarakat Sunda secara administratif hidup di Jawa Barat yang pada dasarnya memiliki tiga jenis topografis (Sumardjo, 2003: 299). Ketiga wilayah topografis itu meliputi: daerah dataran rendah yang membentang dari barat ke timur daerah pantai Jawa Barat; dataran tinggi di sepanjang bagian tengah Jawa Barat yang meliputi Pandeglang, Banten Selatan, Sukabumi, Bogor, Bandung, Sumedang, Majalengka dan Kuningan; daerah sepanjang pantai Selatan Jawa Barat. Daerah topografi yang berada di sepanjang bagian tengah Jawa Barat sangat ideal mengembangkan pertanian ladang atau huma (Sumardjo, 2003: 300) dan ciri-ciri kesundaan lebih mungkin dicari di daerahdaerah tengah dan selatan Jawa Barat, termasuk di dalamnya wilayah Sumedang.

Masyarakat Sunda mengungkapkan berbagai nilai-nilai yang berhubungan dengan atribut kesundaannya melalui bahasa Sunda. Rosidi (2009: 15) menyebut orang Sunda sebagai manusia Sunda yang dalam hidupnya menghayati serta mempergunakan nilai-nilai budaya Sunda.

Pola masyarakat Sunda menurut Sumardjo (2011: 155) adalah hubungan tiga (tripartit), baik vertikal maupun horizontal. Sebagai masyarakat yang hidup berhuma, dunia Sunda adalah kosmos yang terdiri dari langit, bumi dan manusia. Kesatuan tiga vertikal ini dipakai untuk memaknai hidup di dunia manusia, yakni 
tempatnya di alam ini, pengaturan hunian kampung, rumah tinggal dan semua budaya tangible. Sebagai masyarakat agraris yang menggantungkan kehidupan sepenuhnya kepada alam sebagai tempat untuk bercocok tanam, orang Sunda seharusnya senantiasa menjaga dan memelihara alam dengan berbagai perlakuan dan tindakan yang postif secara kolektif. Menurut Supriatna (2016: 29) kemampuan kolektif dalam mengelola lingkungan tempat tinggal serta kegiatan agraris pada masyarakat tradisi merupakan bagian dari kecerdasan ekologis.

Indrawardana (2012: 1-8) lebih jauh lagi menjelaskan bahwa budaya Sunda yang tumbuh dan berkembang dalam lingkungan masyarakat Sunda (termasuk tatanan adat Sunda yang terikat dengan tatali paranti karuhun) memiliki peranan dalam menjaga kelestarian dan keseimbangan alam dalam hubungannya dengan kehidupan masyarakat Sunda. Dalam perkembangannya, kehidupan manusia yang menggantungkan kehidupannya kepada segala sesuatu yang disediakan oleh alam mulai tergerus oleh penetrasi ekonomi pasar yang menyebabkan rusaknya ekosistem.

Masyarakat Sunda dalam kebudayaannya tidak hanya mengenal nama atau perisitilahan alam, tetapi juga memiliki kemampuan menghayati karakter setiap unsur alam. Unsur-unsur alam tersebut dijadikan sebagai pelajaran yang kemudian dianalogikan dalam memandang diri dan manusia lain.

Sumedang merupakan salah satu kabupaten yang mayoritas penduduknya menggunakan bahasa Sunda. Selain itu, Sumedang memiliki potensi budaya yang cukup besar sebagai sumber daya pembangunan daerah seperti beranekaragam kesenian, upacara-upacara adat, ilmu pengetahuan serta cerita rakyat.

Mayoritas penduduk Sumedang merupakan masyarakat agraris yang secara langsung menggantungkan kehidupannya pada hasil-hasil pertanian. Begitupun dengan masyarakat yang berada di Dusun
Cijere, Desa Nagarawangi Kecamatan Rancakalong Kabupaten Sumedang. Masyarakat di Rancakalong masih melaksanakan upacara atau tradisi Bubur Suro. Tradisi ini merupakan salah satu upaya dari masyarakat agraris dalam menjaga kelestarian lingkungan.

Tradisi Bubur Suro adalah salah satu tradisi yang secara turun temurun dan konsisten dilangsungkan oleh masyarakat di dusun Cijere Desa Nagarawangi Kecamatan Rancakalong Kabupaten Sumedang. Menurut Soekanto (1990: 181) tradisi adalah perbuatan yang dilakukan berulang-ulang dalam bentuk yang sama. Tradisi ini secara konsisten dilaksanakan secara rutin tiap tahun, dilakukan pada tanggal 10 Muharam. Tanggal 10 Muharam diyakini oleh sebagian pemeluk agama Islam dianggap sebagai tanggal yang memiliki banyak peristiwa penting.

Dalam kegiatan tradisi Bubur Suro, menurut Anwar dkk (2016) nilai-nilai kehidupan seperti solidaritas di antara warga. Tradisi ini juga betujuan menekan ketegangan di tengah masyarakat (pengendalian sosial), sehingga masyarakat bisa hidup berdampingan secara harmonis. Fungsi lain yang dirasakan oleh masyarakat bahwa tradisi tersebut merupakan upaya dari masyarakat untuk menjaga identitas kelompoknya dalam menghadapi pengaruh buruk yang berasal dari kebudayaan luar.

Penggunaan istilah Suro muncul bukan dari istilah dari pengguna atau pemakai bahasa setempat semata. Penggunaan istilah Suro juga digunakan di daerah lain seperti di Yogyakarta pada tradisi menyambut 1 Syuro. Melalui cerita lisan yang disampaikan secara turun temurun, dapat diketahui bahwa lahirnya tradisi Bubur Suro erat kaitannya dengan upaya leluhur dalam menghadapi kelangkaan pangan serta upaya mencari bibit padi pada masa kerajaan Mataram.

Nilai-nilai kearifan dalam tradisi Bubur Suro penting diwariskan kepada generasi muda disaat berbagai krisis muncul pada diri manusia dan lingkungan 
sekitarnya. Manusia menempatkan alam sebagai sebuah ekosisitem yang saling ketergantungan. Dalam kondisi seperti ini Supriatna (2016: 29) berpendapat bahwa keseimbangan antara manusia dengan alam sebagai tempat untuk bercocok tanam harus senantiasa dijaga dan dipelihara dengan berbagai perlakuan dan tindakan yang positif, di antaranya melalui tradisi atau upacara yang dilakukan secara kolektif. Lebih jauh Supriatna (2016: 24) menjelaskan bahwa kecerdasan ekologis yang dimiliki seseorang individu didasari atas pengetahuan, kesadaran, dan keterampilan hidup yang selaras dengan kelestarian alam.

Berdasarkan latar belakang yang sudah dipaparkan di atas, masalah dalam penelitian ini dapat dirumuskan dalam dua pertanyaan penelitian, yaitu (1) Bagaimana proses pelaksanaan tradisi Bubur Suro? (2) Nilai-nilai kearifan ekologi apa saja yang terdapat dalam tradisi Bubur Suro?

\section{B. METODE PENELITIAN}

Metode penelitian yang digunakan adalah pendekatan deskriptif kualitatif dengan model etnografi. Penelitian kualitatif bersifat deskriptif dan eksplanatoris. Penelitian ini memberikan penjelasan tentang hubungan antara peristiwa dengan makna terutama menurut persepsi partisipan. Selain itu, metode penelitian kualitatif juga sering disebut sebagai metode penelitian naturalistik karena pengumpulan dilakukan pada kondisi yang alamiah, dengan sumber data primer, dan teknik pengumpulan data lebih banyak pada observasi (participant observation), wawancara yang mendalam (in depth interview) dan dokumentasi. Cara pengumpulan data seperti ini biasa juga disebut metode etnografi. Etnografi menurut Spradley (2007: 3) merupakan pekerjaan untuk mendeskripsikan suatu kebudayaan. Lebih jauh Sugiyono (2016: 215) menjelaskan sebagaimana ia mengutip pendapat Spradley, bahwa dalam penelitian kualitatif tidak menggunakan istilah populasi tetapi dinamakan social situation atau situasi sosial yang terdiri dari tiga elemen yaitu tempat (place), pelaku (actors) dan aktivitas (activity) yang berinteraksi secara sinergis.

Dengan demikian studi lapangan yang dilakukan di dalam masyarakat bertujuan untuk mengidentifikasi nilainilai kearifan lokal tradisi Bubur Suro dan lebih jauh lagi melakukan identifikasi terhadap nilai-nilai kearifan ekologis yang terdapat dalam tradisi tersebut. Observasi dilakukan peneliti terhadap pelaksanaan tradisi Bubur Suro, baik yang menyangkut pelaku yang terlibat (actors), pelaksanaannya (activity), maupun tempat (place) dan waktu.

Tujuan dari penelitian deskriptif ini adalah untuk membuat deskripsi, gambaran, atau lukisan secara sistematis, faktual dan akurat mengenai fakta-fakta, sifat-sifat serta hubungan antar fenomena yang diselidiki. Metode ini dipilih karena langkahnya terukur dan dengan hasil yang cukup meyakinkan. Kebenaran yang diungkapkan dapat dibuktikan secara ilmiah. Langkah penelitian yang dilakukan adalah sebagai berikut: 1) studi pustaka, 2) pengembangan kisi-kisi dan instrumen penelitian, 3) pengumpulan data penelitian yaitu dengan wawancara dan observasi, 4) pengolahan dan analisis data, 5) penarikan kesimpulan (Maryani, 2016: 118). Adapun instrumen yang digunakan adalah pedoman wawancara dan observasi lapangan. Kegiatan pengumpulan data berupa wawancara dan observasi dilakukan secara bersamaan.

Penelitian dilakukan pada bulan Oktober 2017 sampai dengan bulan April 2018. Subyek penelitian adalah masyarakat adat yang memiliki kearifan lokal di Dusun Cijere Desa Nagarawangi Kecamatan Rancakalong Kabupaten Sumedang. Informan adalah ketua rurukan, tokoh masyarakat dan agama, kepala desa, pengamat budaya, guru sejarah serta anggota masyarakat lainnya yang dianggap mengetahui dan memahami tentang tradisi Bubur Suro. 


\section{HASIL DAN BAHASAN}

\section{Prosesi Tradisi Bubur Suro}

Tradisi Bubur Suro masih dilaksanakan oleh masyarakat di Dususn Cijere Desa Nagarawangi Kecamatan Rancakalong Kabupaten Sumedang. Data kependudukan Desa Nagarawangi yang ditemukan dalam profil kantor Kepala Desa Nagarawangi menunjukkan bahwa dari 2173 penduduk, 1292 orang di antaranya merupakan petani dan buruh tani. Dengan demikian hampir $60 \%$ penduduknya bermata pencaharian sebagai petani atau mayoritas adalah masyarakat agraris. Selain sebagai petani, terdapat 50 orang sebagai pengrajin gula aren. Adapun hasil tanaman hutan rakyat berupa albasiah, suren, tisuk, bambu dan mahoni. Terdapat dua grup seni Tarawangsa, seni yang menjadi instrumen pengiring dalam kegiatan tradisi Bubur Suro.

Berbagai tradisi yang dilakukan pada masyarakat agraris atau masyarakat pertanian pada umumnya merupakan ungkapan wujud syukur masyarakat terhadap Maha Pencipta sebagai pemberi kehidupan. Wujud syukur itu nampak dalam berbagai makna simbolis, nilai-nilai yang terkandung dalam berbagai ritual tradisi yang memiliki keterkaitan antara sistem kepercayaan, sistem pengetahuan serta praktik-praktik kehidupan masyarakat untuk keberlangsungan hidup manusia dengan penciptanya, manusia dengan manusia, dan manusia dengan alam. Menurut Supriatna (2016: 28) pada masyarakat tradisi, ekositem tidak hanya sistem jejaring dalam lingkungan alam, melainkan juga sebuah sistem yang menempatkan manusia sebagai bagian dari alam.

Hasil penelitian terhadap tradisi di Rancakalong oleh Khairul dkk. (2016) menyebutkan bahwa kecamatan Rancakalong merupakan kecamatan yang paling memenuhi syarat menjadi prototype dari salah satu unsur wilayah Puseur Budaya Sunda. Kearifan lokal yang terdapat di Kecamatan Rancakalong salah satu di antaranya adalah tradisi Bubur
Suro yang secara konsisten dilaksanakan dan dipelihara oleh masyarakatnya. Secara konsisten memiliki arti bahwa masyarakatnya secara rutin melaksanakan tradisi Bubur Suro setiap tahun. Masyarakatnya sendiri berkeyakinan bahwa ada kebahagiaan setelah mereka melaksanakan kegiatan tradisi itu. Sebagai masyarakat agraris, tradisi Bubur Suro yang secara turun temurun terus dilakukan setiap tahunnya berhubungan langsung dengan berbagai aktivitas yang berhubungan dengan pekerjaan, kehidupan keagaamaan, dan sosialnya.

Masyarakat di Dusun Cijere Desa Nagarawangi merasa melakukan pelanggaran terhadap aturan nenek moyang/karuhun (taliparanti karuhun) apabila masyarakat tidak mampu melakukan tradisi Bubur Suro. Dapat dikatakan bahwa nilai-nilai kearifan lokal tersebut masih terpelihara dengan baik dalam masyarakatnya karena masyarakatnya sendiri masih menganggap tradisi tersebut banyak manfaatnya dan memiliki fungsi yang baik bagi keutuhan dan keberlangsungan hidup kelompoknya. Di samping itu, masyarakat menganggap tradisi Bubur Suro juga memiliki fungsi sebagai sarana dalam mengantisipasi berbagai persoalan yang tidak dikehendakinya, baik yang datang dari alam seperti bencana alam maupun persoalan hubungan manusia dengan manusia serta persoalan sosial budaya akibat masuknya pengaruh buruk dari budaya asing. Seperti yang disampaikan Ekadjati (1984: 290) upacara yang dilakukan pada masyarakat etnis Sunda pada dasarnya untuk menghilangkan pengaruh buruk yang datang dari roh-roh halus yang menempati tempat-tempat tinggal manusia.

Sebagai masyarakat agraris yang penduduknya beragama Islam, tujuan utama dari tradisi Bubur Suro adalah sebagai wujud rasa syukur kepada Sang Pencipta, Allah SWT yang telah memberkahi masyarakat serta melimpahkan berbagai keberhasilan 
khususnya dalam bidang pertanian. Wujud syukur itu juga merupakan ungkapan masyarakat sebagai bentuk ibadah antara manusia dengan Allah (Habluminallah), sekaligus sebagai bentuk ibadah antara manusia dengan manusia, serta manusia dengan lingkungan alam (Habluminnanas).

Kegiatan dari upacara Bubur Suro diawali oleh ketua rurukan yang menyampaikan ijab. Ijab merupakan ungkapan rasa syukur yang disampaikan oleh pemimpin adat atau ketua rurukan untuk memulai kegiatan tradisi Bubur Suro. Ijab dibedakan dengan ijab dalam bahasa agama. Ijab dalam bahasa agama, biasanya diawali membacakan doa dengan menggunakan bahasa Arab. Doa sendiri berupa pujian kepada Allah SWT serta menyampaikan shalawat untuk Nabi Muhammad SAW. Adapun ijab dalam bahasa tradisi menggunakan bahasa Sunda yang tetap diawali dengan menyampaikan wujud syukur kepada Allah SWT, shalawat kepada Nabi Muhammad SAW. Tawasul disampaikan juga kepada karuhun yaitu leluhur yang telah meninggal yang dianggap memiliki jasa yang besar bagi masyarakat.

Dalam tradisi lisan (folklore) yang secara turun temurun disampaikan dari satu generasi ke generasi berikutnya, lahirnya tradisi Bubur Suro erat kaitannya dengan perjuangan leluhur (karuhun) dalam menghadapi situasi yang serba sulit ketika daerahnya dilanda paceklik atau krisis pangan. Tradisi lisan yang diakui secara kolektif oleh seluruh warga masyarakat di Dusun Cijere menjadi identitas dan jati diri bagi kelompoknya yang menganggap memiliki sejarah yang sama.

Cerita atau kisah yang disampaikan (folklore) konon berawal dari situasi di mana masyarakat tidak memiliki banyak bahan pangan untuk mencukupi kebutuhan warga masyarakatnya. Kemudian tokoh masyarakat pada saat itu berinisiatif untuk mengumpulkan berbagai jenis bahan makanan yang dimiliki warga masyarakat untuk disatukan dan diolah menjadi bubur, sehingga jumlahnya banyak dan mencukupi kebutuhan masyarakat.

Adapun penggunaan istilah, dan mulai kapan pelaksanaan dari tradisi Bubur Suro, masyarakat tidak mampu menjelaskannya secara rinci. Kondisi ini seperti yang disampaikan Mulyana (2009), bahwa awal pembentukan kearifan lokal dalam suatu masyarakat umumnya tidak diketahui secara pasti kapan kearifan lokal tersebut muncul. Pada umumnya terbentuknya kearifan lokal dimulai sejak masyarakat belum mengenal tulisan (praaksara). Tradisi praaksara ini yang kemudian melahirkan tradisi lisan. Secara historiografi tradisi lisan banyak menjelaskan tentang masa lalu suatu masyarakat atau asal-usul suatu komunitas atau asal-usul adanya sesuatu. Dengan demikian dalam perkembangannya, tradisi lisan ini dapat menjadi kepercayaan atau keyakinan masyarakat.

Pelaksanaan dari tradisi Bubur Suro diawali dengan pengumuman yang disampaikan oleh ketua rurukan secara lisan atas hasil musyawarah. Masyarakat di Dusun Cijere akan mematuhi ketentuan tersebut dengan berbagai persiapan secara sukarela karena ketua rurukan adalah pemimpin bagi mereka, khususnya dalam konteks prosesi adat. Kepatuhan dari warga masyarakat terhadap pemimpinnya didasarkan kepada keyakinan bahwa ketua rurukan adalah sosok kharismatik yang memiliki legalitas, di mana tugasnya sebagai ketua rurukan diperoleh secara turun temurun. Menurut Weber (1968: 358) kharisma digunakan untuk menyebut keadaan (sifat) dari kepribadian seseorang yang dianggap berbeda dari orang biasa dan dianggap diberkati dengan kekuatan adikrodati yang melebihi kekuatan manusia biasa karena diperoleh dari Tuhan.

Biaya pelaksanakan dari tradisi Bubur Suro ditanggung bersama oleh warga masyarakatnya sesuai dengan kemampuannya dan tanpa dipaksa, sehingga masyarakat tidak menjadi beban berat bagi warga masyarakat. Oleh sebab 
itu warga masyarakat akan memberikan apa saja yang dimilikinya tanpa ada patokan yang jelas apa dan berapa yang harus dikumpulkan. Seandainya bahan atau uang tidak ada, warga masyarakat akan turut berpartisipasi serta bergotong-royong guna membantu pelaksanaan upacara adat.

Berbagai bahan yang dibutuhkan dalam tradisi Bubur Suro jumlahnya harus seribu macam (sarebu rupa). Berbagai jenis bahan yang dibutuhkan dalam tradisi Bubur Suro di antaranya beras, beras ketan, jagung, tumbuh-tumbuhan, sayuran, buah-buahan. Selain beras, terdapat juga ubi-ubian seperti ubi jalar, ubi batang/ singkong, talas, kentang. Sedangkan sayursayuran biasanya berupa wortel, terong, labu. Sementara buah-buahan biasanya berupa pepaya, tomat, jeruk atau berbagai jenis buah lokal serta berbagai jenis pisang. Disamping itu juga dimasukkan ikan teri, atau jenis ikan asin lainnya.

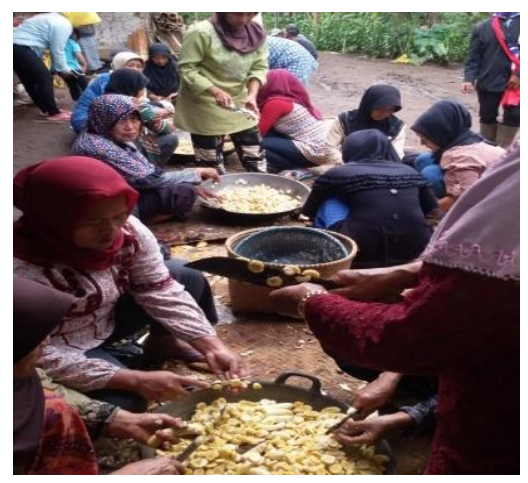

Gambar 1.

Meracik bahan Bubur Suro

Sumber: dokumentasi penulis.

Gula merah menjadi salah satu bahan penting untuk memberikan rasa manis. Gula merah itu sendiri diolah sendiri oleh masyarakat dari air nira yang didapatkan dari pohon kawung/enau. Apabila terjadi kekhawatiran masyarakat terhadap jumlah bahan yang dikumpulkan kurang dari seribu (sarebu rupa), biasanya masyarakat akan memenuhinya dengan tambahan atau menutup dengan pisang sewu, sejenis pisang yang jumlah sisir dalam tandannya sangat banyak. Jenis pisang ini tidak dikategorikan sebagai jenis pisang yang populer dipasaran, tapi sangat penting bagi kebutuhan tradisi. Menurut Khairul dkk (2016) Tradisi Bubur Suro menjadi media pencarian informasi tentang hasil panen sebelumnya. Pencarian informasi itu dilakukan dengan mengumpulkan seribu jenis tanaman baik palawija, sayuran dan buah-buahan. Banyaknya bahan yang dikumpulkan bisa menjadi informasi bagi masyarakat tentang jenis tanaman yang berhasil dipanen dengan baik serta menjadi informasi persoalan yang berhubungan dengan kegagalan panen.

Kegiatan dari tradisi Bubur Suro dibagi menjadi beberapa kelompok kegiatan. Kegiatan mengolah berbagai bahan/meracik dilakukan oleh wanita yang umumnya berumur paruh baya. Hanya sedikit saja generasi muda yang terlibat dalam upacara adat. Generasi muda umumnya terlibat sebagai panitia penyelenggara kegiatan. Meracik bahan bubur dilakukan sejak pagi-pagi dan lansung menuangkannya ke dalam kancah yaitu wajan yang berukuran besar, yang jumlahnya antara tujuh sampai dengan sepuluh buah wajan. Selain memiliki tugas meracik bahan bubur, wanita juga bertugas ngagusruk atau mengolah bubur di atas wajan yang berukuran besar dengan menggunakan susuk kayu panjang. Sementara itu laki-laki bertugas mencari dan menyiapkan hawu atau tungku yang diperoleh dari batang pohon pisang yang sudah tidak digunakan lagi. Di samping itu laki-laki juga bertugas menuangkan gula/ngagulaan ke wajan.

Setelah berbagai jenis bahan diolah dan menghasilkan bubur yang banyak, bubur akan dibagikan kembali kepada masyarakat. Sebagai bahan yang dipakai untuk membungkus bubur digunakan daun pisang yang masih banyak didapatkan di sekitar kebun tempat tinggal warga. Melalui kegiatan Bubur Suro, setiap warga akan berbagi informasi mengenai perkembangan kehidupan masyarakatnya. 
Dengan demikian nilai-nilai solidaritas sesama warga dipelihara dengan baik.

Adapun tugas ketua rurukan sebagai tokoh yang kharismatik, selain memiliki tugas menggerakkan warga masyarakatnya untuk terlibat dalam kegiatan, juga memiliki tugas utama yaitu nyuguh atau menyiapkan sesajen. Sesajen terdiri dari berbagai jenis bahan, penganan serta makanan ringan serta alat-alat yang besifat simbolis. Biasanya alat-alat tersebut dianalogikan sebagai makna yang difahami bersama. Menurut Geerz (1992: 57) jenis simbol-simbol (atau kompleks simbol) yang dipandang oleh suatu masyarakat ini, dianggap sebagai sesuatu yang sakral dan sangat bervariasi.

Berbagai sesajen akan disimpan di salah satu sudut rumah, apabila prosesi Bubur Suro dilakukan di sekitar Rumah adat. Sesajen disimpan di sudut kamar ketua rurukan apabila tradisi dilaksanakan di sekitar rumah ketua rurukan. Kegiatan tersebut seperti yang disampaikan Suryaatmana dkk. (1993) bahwa masyarakat pertanian melaksanakan tradisi kepercayaan adat berupa sesajen, tumbaltumbal hewan, atau benda-benda yang digunakan untuk menanggulangi permasalahan kehidupan karena dipercaya memiliki hubungan dengan alam. Keterikatan masyarakat Sunda dengan alam menurut Suryaatmana dkk. (1993) tidak tunduk terhadap alam tetapi masyarakat Sunda, yang pada umumnya petani, harus menyesuaikan dengan alam sehingga secara tidak langsung alam pun membentuk mentalitas manusia Sunda (para petani masa lalu).

Berbagai sesajen yang senantiasa ada di antaranya tumpeng, bakakak, dawegan, berbagai rurujakan seperti rujak kalapa, rujak cau, dan rujak asem serta berbagai jenis bunga/kembang. Terdapat pula kopi pahit, air teh serta berbagai makanan ringan ciri khas makanan lokal seperti wajit, opak, ranginang, kolontong, ulen. Sesajen lainnya terdapat daun hanjuang, peralatan hidup serta buahbuahan seperti berbagai jenis pisang.
Selain itu, sesajen yang tidak kalah penting adalah dua buah ikatan padi yang dibuat menyerupai boneka. Dua buah ikatan padi tersebut berasal dari padi lokal ranggeuyan serta jenis padi ketan. Dua buah ikatan padi tersebut merupakan boneka yang menyerupai perempuan dan berisi beras dan kebutuhan pokok. Padi ketan merupakan simbol laki-laki dan perempuan. Boneka padi yang menyerupai perempuan merupakan simbol yang dekat dengan rutinitas perempuan, sementara boneka padi ketan merupakan simbol tanggung jawab laki-laki dalam bekerja. Beras ketan sendiri sebagai bahan dasar dari berbagai jenis makanan yang menjadi simbol banyaknya jenis pekerjaan yang bisa dilakukan oleh laki-laki. Dua buah boneka padi tersebut juga merupakan simbol Kersa Nyai, simbol perempuan sebagai patih goah di mana perempuan merupakan orang yang bertanggung jawab dalam mengelola perekonomian keluarga.

Goah pada masyarakat pedesaan merupakan satu tempat yang biasanya berada di bagian belakang rumah untuk menyimpan berbagai hasil pertanian seperti padi yang sudah dikeringkan atau beras sebagai persedian di masa yang akan datang. Perempuan memiliki tugas (patih) sebagai lambang ketahanan pangan dari sebuah keluarga, lebih jauh lagi merupakan simbol ketahanan pangan masyarakat.

Selama kegiatan tradisi Bubur Suro dilangsungkan, baik yang dilaksanakan di bale adat, maupun yang dilaksanakan di sekitar rumah ketua rurukan, biasanya diiringi dengan seni Tarawangsa. Tarawangsa sebagai instrumen pengiring terdiri dari dua jenis alat musik yaitu rebab dan kecapi. Dua alat musik ini sangat erat dengan ciri musik masyarakat agraris. Menurut Sumardjo (1992: 6), kesenian yang berkembang pada masyarakat agaris atau pertanian yang mengharuskan masyarakatnya untuk selalu berpindahpindah, sangat berpengaruh pada bentuk dan keseniannya yang sederhana dan mudah dibawa-bawa. Dengan demikian di bale adat masyarakat biasa berkumpul, 
bergotong royong, bekerjasama, bahu membahu, berbagi tugas/pekerjaan sesuai keahliannya, berkomunikasi bahkan bercengkrama dan menikmati alunan musik serta tarian yang mengiringi seni Tarawangsa. Istilah Tarawangsa sendiri merupakan akronim dari menerawang yang Maha Kuasa.

Masyarakat di Dusun Cijere Desa Nagarawangi Kecamatan Rancakalong sebagai pemelihara tradisi Bubur Suro dalam kehidupan sehari-harinya tidak lepas dari banyak simbol-simbol budaya yang sarat dengan pesan-pesan kehidupan. Pesan-pesan moral itu senantiasa dipelihara dalam bentuk silib siloka sasmita, penuh dengan simbol-simbol makna yang diyakini oleh masyarakatnya memiliki fungsi sebagai upaya menyelaraskan kehidupan yang saling berkesinambungan. Salah satu ungkapan itua dalah mipit kudu amit ngala kudu bebeja, memiliki arti memetik harus permisi dan mengambil harus memberi tahu atau meminta. Ungkapan ini merupakan pesan untuk memperlakukan lingkungan sekitar dengan tertib sesuai aturan dan tidak mengambil dan memetik yang bukan menjadi miliknya. Ungkapan ini juga sekaligus menjadi pedoman bagi warga masyarakat untuk tidak merusak alam semena-mena karena alam memiliki pemiliknya yaitu Sang Pencipta.

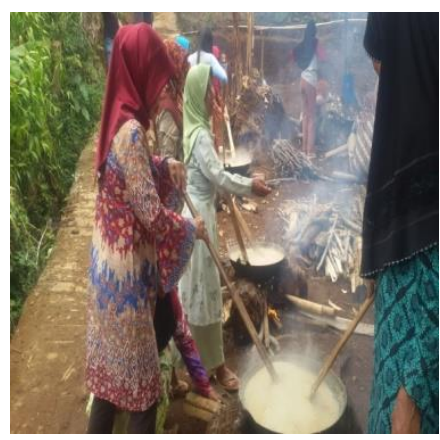

Gambar 2. Ngagusruk Sumber: dokumentasi penulis.
Tabel 1. Nilai-Nilai Kearifan Lokal Tradisi Bubur Suro

\begin{tabular}{|c|c|c|c|}
\hline No & $\begin{array}{l}\text { Sistem } \\
\text { Budaya }\end{array}$ & $\begin{array}{c}\text { Nilai- } \\
\text { Nilai } \\
\text { Kearifan } \\
\text { Lokal }\end{array}$ & Keterangan \\
\hline \multirow[t]{3}{*}{1} & \multirow[t]{3}{*}{ Keyakinan } & $I j a b$ & $\begin{array}{l}\text { Doa } \\
\text { mengawali } \\
\text { kegiatan }\end{array}$ \\
\hline & & Taliparanti & $\begin{array}{l}\text { Aturan lisan } \\
\text { yang } \\
\text { disepakati } \\
\text { secara } \\
\text { kolektif/Susta } \\
\text { inability }\end{array}$ \\
\hline & & $\begin{array}{l}\text { Folklore } \\
\text { tentang } \\
\text { sejarah } \\
\text { Bubur } \\
\text { Suro }\end{array}$ & $\begin{array}{l}\text { Kebanggaan } \\
\text { terhadap } \\
\text { identitas } \\
\text { sejarah } \\
\text { kelompoknya }\end{array}$ \\
\hline 2 & Pengetahuan & $\begin{array}{l}\text { Sarebu } \\
\text { rupa }\end{array}$ & $\begin{array}{l}\text { Pengetahuan } \\
\text { tentang } \\
\text { keanekaraga } \\
\text { man } \\
\text { hayati/Sustain } \\
\text { ability }\end{array}$ \\
\hline \multirow[t]{5}{*}{3} & \multirow[t]{5}{*}{ Pemahaman } & Kersa Nyai & $\begin{array}{l}\text { Perlindungn/k } \\
\text { onservasi } \\
\text { terhadap jenis } \\
\text { padi lokal }\end{array}$ \\
\hline & & $\begin{array}{l}\text { Ungkapan } \\
\text { Sarereaeun }\end{array}$ & $\begin{array}{l}\text { Kesinambung } \\
\text { an/Sustainabi } \\
\text { lity }\end{array}$ \\
\hline & & $\begin{array}{l}\text { Dawegan } \\
\text { dipares }\end{array}$ & $\begin{array}{l}\text { Simbol hidup } \\
\text { rapi dan tertib } \\
\text { sesuai aturan }\end{array}$ \\
\hline & & Bakakak & $\begin{array}{l}\text { Simbol } \\
\text { pemimpin } \\
\text { yang bisa } \\
\text { dipercaya } \\
(\text { brukbrak) } \\
\end{array}$ \\
\hline & & Tumpeng & $\begin{array}{l}\text { Symbol } \\
\text { pemimpin } \\
\text { kerja keras } \\
\text { (ngawujud) }\end{array}$ \\
\hline \multirow[t]{2}{*}{4} & \multirow[t]{2}{*}{ Wawasan } & $\begin{array}{l}\text { Patih } \\
\text { Goah }\end{array}$ & $\begin{array}{l}\text { Perempuan } \\
\text { sebagai } \\
\text { symbol } \\
\text { ketahanan } \\
\text { pangan }\end{array}$ \\
\hline & & $\begin{array}{l}\text { Sarebu } \\
\text { rupa }\end{array}$ & $\begin{array}{l}\text { Media } \\
\text { informasi } \\
\text { keberhasilan }\end{array}$ \\
\hline
\end{tabular}




\begin{tabular}{cll}
\hline \multirow{2}{*}{} & & pertanian \\
\cline { 2 - 3 } & $\begin{array}{l}\text { Mipit kudu } \\
\text { amit ngala } \\
\text { kudu } \\
\text { bebeja }\end{array}$ & $\begin{array}{l}\text { Perlindungan } \\
\text { terhadap } \\
\text { pengrusakan } \\
\text { lingkungan / } \\
\text { Sustainability }\end{array}$ \\
\hline $5 \quad \begin{array}{l}\text { Adat } \\
\text { kebiasaan } \\
\text { atau etika }\end{array}$ & $\begin{array}{l}\text { Gotong - } \\
\text { royong }\end{array}$ & $\begin{array}{l}\text { Kerjasama } \\
\text { dalam } \\
\text { berbagai } \\
\text { kegiatan }\end{array}$ \\
\cline { 2 - 3 } & Solidaritas & $\begin{array}{l}\text { Kesinambung } \\
\text { an/Sustainabi } \\
\text { lity }\end{array}$ \\
\hline
\end{tabular}

Sumber: Diolah pribadi dari hasil penelitian

\section{Nilai-Nilai Kearifan Ekologis Tradisi Bubur Suro}

Berbagai jenis kearifan lokal di beberapa daerah atau kampung adat dianggap ampuh dalam menghadapi persoalan lingkungan. Kearifan lokal leuweung tutupan di Kampung Naga atau kearifan lokal leuweung larangan $\mathrm{di}$ wilayah masyarakat Baduy sangat efektif mencegah masyarakat untuk merambah hutan atau mengambil berbagai kekayaan hutan dengan alasan takut ancaman gangguan mahluk halus. Kearifan lokal tersebut secara khusus merupakan kearifan ekologis. Kearifan ekologis merupakan bentuk kearifan masyarakat dalam menjaga dan memperlakukan alam secara bijak agar terhindar dari pengrusakan lingkungan.

Manusia seperti halnya dengan makhluk hidup berinteraksi dengan lingkungan hidupnya. Manusia memengaruhi lingkungan hidupnya dan sebaliknya, ia juga dipengaruhi lingkungan hidupnya (Soemarwoto, 2009: 18-19). Menurut Supriatna (2016: 29) kearifan ekologis tersebut sebagai sebuah kecerdasan ekologis masyarakat tradisi berupa pemahaman masyarakat tentang daya dukung alam yang diwujudkan dalam tindakan nyata untuk menjaga lingkungan tempat tinggal (sustainability). Kecerdasan ekologis ini merupakan cara pandang ekosentris yang menempatkan manusia sebagai sahabat alam (Supriatna, 2016:
110). Sementara menurut Iskandar (2016), sebagaimana ia mengutip Toledo menyatakan bahwa pada masa silam, sebelum sistem ekonomi pasar masuk deras ke berbagai pelosok pedesaan di Indonesia, pada umumnya hubungan timbal balik penduduk desa dengan sumber daya alam dan lingkungannya didasari oleh sistem kompleks yang disebut corpuscosmospraxis. Dengan kata lain, bahwa berbagai praktik penduduk (praxis) lokal dalam mengeloladan memanfaatkan sumber daya alam, biasanya dilandasi kuat oleh sistem kepercayaan (cosmos) dan sistem pengetahuan/kognitif (corvus) mereka.

Bagi masyarakat yang mayoritas penduduknya menggantungkan kehidupan pada alam, biasanya alam dijadikan bagian penting dalam perjalanan hidup mereka. Pengalaman menghadapi berbagai fenomena alam mengantarkan manusia memiliki banyak pengetahuan dan ketrampilan yang diajarkan oleh alam, bahkan didorong untuk senantiasa memanfaatkan berbagai potensi yang disediakan oleh alam dengan bebagai keanekaragaman hayati. Berbagai kebutuhan yang berhubungan dengan tradisi Bubur Suro seluruhnya didapatkan dari alam sekitar lingkungan tempat tinggal masyarakat.

Bahan utama yang dibutuhkan untuk mengolah bubur jumlahnya harus seribu macam (sarebu rupa). Konsep sarebu rupa diterjemahkan tidak persis seribu jenis, akan tetapi dimaknai sebagai jumlah yang banyak. Sarebu rupa merupakan upaya dari kelompok masyarakat pemelihara tradisi Bubur Suro untuk melangsungkan kesinambungan (sustainability), termasuk di dalamnya adalah konservasi atau proteksi terhadap berbagai jenis keanekaragaman hayati (diversitas hayati).

Berbagai jenis bahan yang harus ada seperti beras dan beras ketan yang berasal dari jenis padi lokal akan menyelamatkan jenis padi lokal dari ancaman derasnya beras impor. Hal tersebut tercermin dari simbol kersa nyai. 
Selain itu, gula merah (gula kawung) sebagai bahan pemanis bubur yang diolah dari nira pohon kawung dengan sendirinya akan melindungi pohon kawung dari penebangan untuk berbagai kepentingan. Larangan secara lisan untuk menebang pohon kawung kecuali tidak lagi produktif, atau tersambar petir merupakan upaya lain perlindungan terhadap pohon kawung. Pohon kawung sendiri selain diambil air niranya, dapat menjadi bahan buah kolang-kaling (caruluk) yang menjadi makanan bagi musang. Jenis tanaman keras lainnya selain kawung, yaitu pohon kelapa yang buah kelapanya dijadikan sebagai dawegan, pelengkap sesajen. Sedangkan pohon bambu, bambunya digunakan untuk berbagai kebutuhan penunjang seperti membuat tiang-tiang balandongan.

Sementara cau sewu (pisang sewu) sebagai penutup pada bahan bubur agar jumlahnya dianggap seribu jenis dengan sendirinya merupakan jenis pohon pisang yang harus dilindungi. Sedangkan daun pisang yang dimanfaatkan sebagai alat untuk membungkus bubur merupakan bentuk tindakan ramah lingkungan, karena sampah bekas pembungkus bubur berupa daun pisang dapat dikategorikan sebagai sampah organik yang mudah terurai.

Jenis tumbuhan lain yang wajib ada di antaranya umbi-umbian yang terdiri dari singkong, kentang, ubi dan talas. Sedangkan buah-buahan sebagai pelengkap ada berbagai jenis pisang, pepaya, labu, tomat serta berbagai jenis buah-buahan lokal lainnya. Begitupun dengan berbagai jenis sayur-sayuran. Berbagai tanaman pendukung dalam tradisi Bubur Suro didapatkan baik dari jenis tanaman keras sampai dengan tanaman berbentuk perdu.

Sementara itu perlindungan terhadap jenis unggas tampak pada simbol bakakak yaitu sejenis penganan yang berasal dari daging ayam kampung yang dibakar dengan tanpa memotong-motong dagingnya. Sekalipun peternakan ayam bukan ras mulai banyak ditemukan, akan tetapi tidak bisa menggantikan jenis ayam kampung untuk keperluan tradisi. Selain digunakan sebagai bentuk perlindungan terhadap berbagai jenis tanaman dan unggas lokal, keanekaragaman hayati juga berfungsi untuk menjaga kesinambungan alam.

Menurut Khairul dkk (2016) masyarakat Sunda memiliki pandangan hidup (way of life) yang bergantung dengan alam dan lingkungannya merupakan, yaitu melalui konsep hirup nu hurip. Ungkapan hirup nu hurip berarti mengukur hidup manusia yang dilihat dari bagaimana kebermanfaatan individu (dirinya) terhadap orang lain dan semesta alam (kewajiban azasi manusia). Melihat hal tersebut, jelas bahwa orang Sunda dalam kehidupannya menganggap dirinya bukan suatu agen bebas di dalam kosmosnya, namun merupakan bagian dari suatu keseluruhan kehidupan yang besar. Hal ini selaras dengan pandangan antroposentris yang menganggap bahwa manusia adalah sahabat alam.

Masyarakat di Dusun Cijere memandang bahwa manusia adalah sahabat alam melalui konsep sarereaeun. Hal tersebut ditunjukkan dengan menjalin hubungan yang harmonis, bukan hanya manusia dengan manusia saja, tetapi juga terciptanya hubungan yang harmonis antara manusia dengan seluruh mahluk hidup yang ada di lingkungannya. Sekecil apapun perlakuan manusia terhadap alam dalam konsep sarereaeun akan berpengaruh besar terhadap mahluk hidup yang ada serta alam itu sendiri. Kesinambungan alam dalam konsep sarereaeun tercermin juga dalam berbagai ungkapan seperti mipit kudu amit ngala kudu bebeja yang menunjukkan kearifan untuk tidak mengambil milik dan merusak barang orang lain, termasuk pula untuk tidak mengambil, merusak tanaman serta berbagai unggas dan binatang. Selain itu, ungkapan lainnya banyak terungkap dari kata-kata yang berkaitan dengan lingkungan seperti pohon, bunga, air, tempat, sungai, gunung atau hutan. 
Adapun konsep patih goah yang memposisikan perempuan sebagai lambang ketahanan pangan merupakan pemahaman masyarakat dalam upaya memanfaatkan hasil-hasil pertanian sesuai dengan kebutuhan, serta mempersiapkan sejak dini terhadap ancaman paceklik. Hal tersebut dapat membiasakan keluarga untuk hidup sederhana dan hemat. Ketahanan pangan keluarga akan berpengaruh terhadap terciptanya ketahanan pangan lokal.

Kearifan ekologis yang dimiliki masyarakat pemelihara tradisi Bubur Suro berupa usaha menjaga keanekaragaman hayati serta konservasi berbagai jenis tanaman, merupakan salah satu bentuk respon masyarakat dalam menghadapi maraknya pengerusakan dan pencemaran lingkungan. Selain itu, masyarakat pemelihara tradisi Bubur Suro berupaya mewujudkan taliparanti sebagai amanat leluhur sekaligus menjadi identitas bagi warganya dalam menangkal berbagai pengaruh buruk pengerusakan lingkungan oleh pihak-pihak yang tidak bertanggungjawab. Salah satu contohnya adalah akibat perusahaan-perusahaan besar yang mencari keuntungan semata, tanpa memperhatikan lingkungan. Perusahaan skala besar biasanya mengganti beragam jenis tanaman dengan satu jenis tanaman yang sama tanpa mempertimbangkan dampak yang ditimbulkan.

\section{PENUTUP}

Tradisi Bubur Suro di Dusun Cijere Desa Nagarawangi Kecamatan Rancakalong Kabupaten Sumedang merupakan tradisi yang secara turun temurun dilaksanakan oleh masyarakatnya sebagai peninggalan leluhurnya. Prosesi pelaksanaan tradisi Bubur Suro terdiri dari rangkain kegiatan yang melibatkan seluruh warga masyarakatnya untuk berpartisipasi secara aktif dan menjadikan tradisi tersebut sebagai media untuk berkomunikasi dengan warga masyarakat, baik yang menyangkut hubungan manusia dengan manusia, hubungan manusia dengan alam sekitarnya, maupun hubungan manusia dengan Sang Pencipta.

Prosesi Bubur Suro diawali dengan ijab sebagai bentuk wujud syukur kepada Sang Pencipta, dilanjutkan dengan prosesi nyuguh yang dilakukan oleh ketua rurukan. Meracik bahan bubur dilakukan oleh perempuan, sementara membuat hawu (tungku) dilakukan oleh laki-laki. Setelah proses meracik selesai, dilanjutkan pada proses ngabubur (mengolah bubur) dan diakhiri dengan proses membagikan bubur. Selama dalam pelaksanaannya, tradisi Bubur Suro diiringi musik Tarawangsa.

Tradisi Bubur Suro tidak sekadar kegiatan untuk mengumpulkan warga untuk ngabubur (memasak bubur), kemudian hasilnya dibagikan kepada warga masyarakat. Akan tetapi, tradisi ini merupakan tindakan nyata yang dilakukan oleh masyarakat untuk menyelamatkan lingkungan alam dari ancaman pengrusakan ekosistem yang akan mengancam keberlangsungan makhluk hidup. Dengan demikian nilai-nilia kearifan lokal tradisi Bubur Suro memiliki nilai-nilai kearifan ekologis yaitu (1) ijab merepresemtasikan tindakan nyata dalam memperlakukan alam dengan bijak merupakan gambaran masyarakat yang religius, yang meyakini bahwa melimpahnya sumber daya alam merupakan anugrah Yang Maha Kuasa yang harus disyukuri; (2) taliparanti, dawegan dipares, hidup tertib sesuai aturan, dengan tidak melakukan pengrusakan terhadap alam; (3) sarebu rupa, kersa nyai, bakakak merupakan upaya menjaga dan memelihara berbagai keaneka ragaman hayati yang dapat berguna dalam memenuhi kebutuhan hidup, sekaligus dapat menjadi upaya konservasi berbagai jenis tanamana lokal yang penting dalam menjaga ekosistem; (4) sarereaeun, ketika ekosistem dirusak dengan mengubah keanekaragaman hayati menjadi tanaman homogen, dengan sendirinya hal tersebut akan mengancam keberlangsungan hidup manusia; (5) patih goah dengan hidup hemat memanfaatkan 
alam sesuai kebutuhan; dan (6) gotong royong dalam mengatasi persoalan lingkungan.

Upaya masyarakat melibatkan generasi muda dalam kegiatan tradisi merupakan langkah baik untuk melestarikan tradisi Bubur Suro sebagai wujud kesadaran dari masyarakat tentang manfaat tradisi tersebut terhadap lingkungan. Hasil identifikasi terhadap nilai-nilai kearifan ekologis dalam tradisi Bubur Suro dapat direkomendasikan sebagai materi bahan ajar sejarah yang berbasis kearifan lokal.

\section{UCAPAN TERIMA KASIH}

Ucapan terima kasih saya haturkan kepada ketua Prodi Pendidikan Sejarah SPs UPI Dr. Leli Yulifar, M.Pd., Tim Pembimbing Prof. Dr. Didin Saripudin dan Prof. Nana Supriatna, M.Ed., Kepala Desa Nagarawangi - Rancakalong, Ketua Rurukan Dusun Cijere Desa Nagarawangi, dan kepada seluruh pihak yang membantu dalam penelitian ini.

\section{DAFTAR SUMBER}

\section{Jurnal}

Anwar, Rully Khairul., Edwin Rizal, Evi Novianti, Dadang Sugiana. "Adaptasi Media Interaksi Sosial Tradisional Terhadap Modernisasi: Filsafat Komunikasi di Rancakalong" dalam Jurnal Aqidah dan Filsafat Islam Vol 1 (1) 2016. Hlm. 83-104.

Indrawardana, Ira. "Kearifan Lokal adat Masyarakat Sunda dalam Hubungan dengan Lingkungan Alam" dalam Jurnal Komunitas Vol. 4 (1) 2012. Hlm. 1-8.

Maryani, Enok dan Ahmad Yani. "Kearifan Lokal Masyarakat Sunda Dalam Memitigasi Bencana dan Aplikasinya Sebagai Sumber Pembelajaran IPS Berbasis Nilai" dalam Jurnal Penelitian Pendidikan UPI Vol. 14 (2) 2014. Hlm. 114-125.

Iskandar, Johan. "Etnobiologi dan Keragaman Budaya di Indonesia" dalam Umbara Indonesian Journal of Anthropology Vol. 1 (1) Juli 2016. Hlm. 27-42.
Unayah, Nunung dan Muslim Sabarisman. "Identifikasi Kearifan Lokal dalam Pemberdayaan Komunitas Adat Terpencil" dalam jurnal SosioInforma Kemensos Vol .2, No 1, Januari-April 2016. Hlm 4-10.

\section{Buku}

Danandjaja, James. 1984.

Folklor Indonesia: Ilmu Gosip,

dongeng, dan lain-lain. Jakarta: Pustaka Utama Grafiti.

Ekadjati, Edi S. 1984.

Masyrakat Sunda dan Kebudayaannya. Bandung: Girimukti Pasaka.

Geertz, Clifford. 1992.

Kebudayaan dan Agama. Yogyakarta: Kanisius.

Kaplan, David dan Robert A. Manners. 2012. Teori Budaya. Yogyakarta: Pustaka Pelajar.

Keraf. 2010.

Etika Lingkungan Hidup. Jakarta: Buku Kompas.

Mulyana, Agus. 2009.

Mengembangkan Social Skills Dalam Pembelajaran IPS di Sekolah. Bandung: UPI.

Nasiwan dan Cholisin. 2012. Dasar-Dasar Ilmu Politik. Yogyakarta: Ombak.

Rosidi, Ajip. 2009. Manusia Sunda. Bandung: Kiblat Buku Utama.

Sedyawati, Edi. 2012. Budaya Indonesia Kajian Arkeologi, Seni dan Sejarah. Jakarta: Raja Grafindo Perkasa.

Setiyadi, Putut. 2012.

Pemahaman Kembali Local Wisdom Etnik Jawa dalam Tembang Macapat dan Pemanfaatanna sebagai Media Pendidikan Budi Pekerti Bangsa. Malang: Universitas Widya Dharma.

Sibarani, Robert. 2012.

Kearifan Lokal, Hakikat, Peran dan Metode Tradisi Lisan. Jakarta: ATL.

Spradley, James. 2007. 
Metode Etnografi. Yogyakarta: Tiara Wacana.

Soekanto, Soerjono. 1990.

Sosiologi Suatu Pengantar. Jakarta:

Rajawali Pers.

Soemarwoto, Otto. 2009

Analisis Mengenai Dampak

Lingkungan. Yogyakarta: Gadjah Mada

University.

Supriatna, Nana. 2016.

Ecopedagogy Membangun Kecerdasan Ekologis dalam Pembelajaran IPS.

Bandung: Remaja Rosdakarya.

Sugiyono. 2016.

Metode Penelitian Kuantitatif, Kualitatif dan $R \& D$. Bandung: Alfabeta.

Sumardjo, Jakob. 1992.

Perkembangan Teater Modern dan

Sastra Drama Indonesia. Bandung:

Citra Aditya Bakti. 2003.

Simbol-simbol Artefak Budaya Sunda, Tafsir-tafsir Pantun Sunda. Bandung: Kelir. 2011.

Sunda Pola Rasionalitas Budaya. Bandung: Kelir.

Suryaatmana, E, Darsa, Undang Ahmad and Erlyane, Ane and Wartini, Tien, 1993.

Paririmbon Sunda: Jawa Barat. Jakarta: Direktorat Sejarah dan Nilai Tradisional

Weber, Max. 1986.

On Charisma and Institution Building. Chicago: University of Chicago. 